\title{
A pedagogy of biocentric relationality
}

\author{
Jenny Ritchie
}

Unitec Institute of Technology, Auckland

\begin{abstract}
This paper theorises some implications for pedagogies for 'sustainabilities' in the light of the current climate crisis, reflecting particularly upon the work of eco-feminist philosopher, Rosi Braidotti, in order to re-imagine a pedagogy of biocentric relationality. A notion of complex, inter-related sustainabilities is promoted as holding pedagogical promise in response to the ecological and cultural challenges of our times. The discussion then moves to focus on Aotearoa as a site for place-based pedagogies founded in local Indigenous understandings. Lastly, some examples from a recent study within early childhood care and education settings in Aotearoa are employed to illustrate some pedagogical possibilities.
\end{abstract}

\section{Introduction}

It is becoming increasingly evident that our planet is facing an ecological crisis of alarming proportions, and that humans need to radically change our behaviour if we are to intervene in this calamity (Hansen, 2009). According to James Hansen, a preeminent climate scientist and director of NASA's Goddard Institute for Space Studies, "dangerous anthropogenic interference" in our planet's ecosystem is already at a critical level (as cited in Kolbert, 2009, June 29, p. 42). Disastrously for the planet, there has been an ongoing lack of political will on the part of the 'developed' countries to commit to the substantial measures needed to address the climate crisis, such as those being promulgated by the United Nations Framework Convention on Climate Change and the Kyoto Protocol (Magdoff \& Foster, 2011).

Despite ongoing international tensions and reluctance of many of the 'developed' nations, including New Zealand, to commit to a meaningful agreement on reducing the carbon emissions that directly exacerbate the global climate crisis, there has been a growing awareness amongst critical scholars of our ethical responsibility to elicit through our teaching, and research, an activist response to the global ecological crisis (Coole \& Frost, 2010). The urgent need for educational activism has been recognised by the United Nations Educational Scientific and Cultural Organisation (UNESCO), the lead agency for the United Nations Decade of Education for Sustainable Development (DESD), 2005-2014. In recognition of the strategic importance of teacher education in reorienting education systems to address sustainability UNESCO has been fostering an international group of national networks of teacher education institutions who have made a commitment to the goal of 'Reorienting Teacher Education towards Sustainability' (UNESCO, 2005; UNESCO, 2010).

After backgrounding some of the complexities involved in such a commitment by problematising notions of 'sustainable development' and 'sustainability', this article considers what adopting such a commitment might entail for education in Aotearoa, with regard to our particular geo-political and bio-regional setting and the implications for particular pedagogies of place. Drawing on Plumwood (1999, 2002, 
2006), Braidotti (2006, 2010), and also following the work of Rose (2001) and Haraway $(1997,2000,2008)$, a postanthropocentric, ethopolitical approach will be suggested which involves a reconceptualisation of pedagogies "in terms of affectivity, interrelationality, ecophilosophical resources, locations, and forces" (Braidotti, 2010, p. 209) and which operate in service of a "bio-centered egalitarianism" (Braidotti, 2006, p. 199). Following Haraway's call to embrace with "empathy, accountability and recognition" an "enlarged sense of community" (1997, as cited in Braidotti, 2006, p. 200), this pedagogy is similarly informed by local Indigenous ways of being, knowing and doing, whereby the interconnectedness and interdependence of humans with the more-than-human world (Plumwood, 1999), is affirmed as fundamental (Marsden, 2003). The article concludes with excerpts from some narratives gathered during a recent research project (Ritchie, Duhn, Rau, \& Craw, 2010) which offers several examples of "the multiple micropolitical modes of daily activism" (Braidotti, 2010, p. 210) that a range of teachers, children and families demonstrated during the project.

\section{Problematising 'sustainability': reorienting towards relational sustainabilities}

Plumwood (2002) points out how the massive processes of biospheric degradation that have been generated through industrialisation have become normalised to the point that they are largely ignored, despite the increasing signs of a planet in distress. She considers that the "often-invoked term 'sustainability' tends to obscure the seriousness of the situation" (Plumwood, 2002, p. 1). She questions the 'rationality' of the hegemonic forces of the Western project of unfettered globalised forms of capitalism which rely on exploitation of people and the planet for profit, and which operate in denial of the severe consequences of its impacts. Current paradigms for understanding constructs of sustainability are heavily influenced by dominant neoliberal discourses which privilege the 'free' market (Plumwood, 2002) and 'the economy' above the status and wellbeing of the majority of the world's citizens as well as that of the planet. Critical for the work of teacher education and education is to respond to Plumwood's challenge that the dominance of marketdriven instrumentalist paradigms "distort our sensitivity to and knowledge of nature, blocking humility, wonder and openness in approaching the more-thanhuman, and producing narrow types of understanding and classification that reduce nature to raw materials for human projects" (Plumwood, 1999, pp. 196-197).

Environmentalists (and many Indigenous peoples) hold alternative understandings, in which the phrase 'sustainable development' is viewed as oxymoronic, since clearly the exploitation of finite resources cannot be sustained indefinitely (Davidson, 2011, p. 352). Furthermore, there is a recognition that societies cannot and should not be sustained by economic growth and consumption alone. In this view there can be no such thing as 'sustainable development'. Even notions of 'development' are problematic, as they are loaded with imperialist, colonialist baggage presuming a hierarchical linear trajectory from inferior 'primitive', 'underdeveloped' peoples to 'civilised', industrialised, consumerist Western societies. 
There is currently a rapidly increasing inequitable division globally between socalled 'developed' countries and those which are on different or slower trajectories:

The combined wealth of the three richest people in the world exceeds the gross domestic products of the 48 poorest countries and the combined wealth of the 225 richest people is roughly equal to the annual income of the poorest $47 \%$ of the world's population. Roughly 3 billion people struggle to sustain themselves on less that US\$2 a day. There are 852 million people across the world who suffer from chronic or acute hunger... All this misery despite the fact that a mere fraction of what the United States currently spends on the military could end world hunger as we know it. (Scatamburlo-D’Annibale \& McLaren, 2009, p. 98)

Meanwhile, although the ecological 'footprint' of those of us living in 'developed' countries is patently unsustainable, many people around the world clamour for the consumerist comforts they see paraded in Western media. Yet Indigenous, precapitalist societies lived comparatively sustainably over extended periods of time, many fostering non-individualistic values such as cooperation and contribution to the collective, as well as respect for the environment (Magdoff \& Foster, 2011).

The current extreme neoliberal focus which privileges multinational corporate profit above the wellbeing of people and planet, aptly described as "the cannibalisation of nature by a global market" (Braidotti, 2007, p. 70), has generated a hegemonic apathy which is only now beginning to be awakened despite the warnings of prophetic environmental philosophers such as Rachel Carson (1962, as cited in Curry, 2011) and Plumwood $(1999,2002,2006)$. "There is great potential for agency toward affecting a symbiotic balance between our species and the larger ecological world around us. However, most people remain largely inactive, with eyes closed to the potential role we could play as stewards of a planet inhabited by multitudes of life forms in an ecological balance" (Riley-Taylor, 2003, p. 41). As educators we need to consider our role with regard to challenging this apathy.

Rationalist instrumentalist approaches as well as dualistic constructions such as the human/nature, mind/body, rational/emotional binaries have created a sense of separation, distancing and alienation between people and the planet. "'Separation' as a way of knowing has kept us from experiencing how deeply our lives are interwoven within the fabric of the ecological world" (Riley-Taylor, 2003, p. 41). We are currently and recurrently witnessing the accelerating effects of the climate crisis, such as recent flooding in areas affected by massive deforestation such as Thailand and the Philippines, which can no longer be viewed purely as 'acts of nature' since these "allegedly 'natural' catastrophes" are actually a complex and dangerous "hybrid mix of cultural and political forces" (Braidotti, 2010, p. 207). It is timely, then, for educationalists to respond to the challenge to 'reweave' the threads that bind humans to their place in the world, since "education is a prime medium in which to initiate an educational praxis which draws on ecological and spiritual tenets of relationality and connection-making" (Riley-Taylor, 2003, p. 41). 


\section{Activism sourced in an ethics of relationality}

Clearly there is an urgent need for rethinking and imagining the present and possible futures for the human/planet inter-relationship. Braidotti's (2010) prophetic vision is to propose "the politics of 'life itself' as a form of active ethical citizenship" (p. 204). She suggests that what is required is an active ethical transformation: "This is not a leap of faith, but an active transposition, a transformation at the indepth level" which is motivated by a yearning for sustainable futures (Braidotti, 2006, p. 207). For Braidotti (2009):

The sustainability of these futures consists in [our] being able to mobilise, actualise and deploy cognitive, affective and collective forces which had not so far been activated... We have to learn to think differently about ourselves. To think means to create new concepts. (p. 45)

A central adjustment in our thinking invoked by Braidotti (2009), is to broaden the horizon of our ethics of relationality to include "inter-relations with non-human, post-human and inhuman forces" (p. 45). This relational ethic is central to an ecophilosophy that recognises and values humanity's reliance on and interdependence with our environment, involving a "biocentered egalitarianism" (Braidotti, 2010, p. 204). This requires a vision of "an enlarged sense of inter-connection between self and others" (Braidotti, 2009, p. 47), and a correspondingly enlarged sense of community which is inclusive of both humans and more-than-human or 'earth' others, including planetary forces. Braidotti (2009) considers that "This practice of relating to others requires and is enhanced by the rejection of self-centred individualism" (p. 47). It opens up "an ecophilosophical dimension of reflection and inaugurates alternative ecologies of belonging" inclusive of environmental interconnectedness (Braidotti, 2010, p. 204).

Braidotti (2010) is sensitive to the traumatic nature of such hugely transformational work, issuing the 'cautionary note' that the required processes of change and transformation:

are so important [...] that they have to be handled with care. The concept of ethical sustainability addresses these complex issues. We have to take pain into account as a major incentive for, [...] an ethics of changes and transformations. We also need to rethink the knowing subject in terms of affectivity, interrelationality, ecophilosophical resources, locations, and forces. (p. 209)

Following Deleuze and Guattari's (2004a, 2004b) work validating the intense energy of desire (Tuck, 2010), Braidotti poses a profound challenge to the educational project focusing on transformation for sustainabilities. This is to shift our educational frame from one which prioritises cognition, to one which recognises the primacy of emotion: "This implies approaching the world through affectivity and not cognition: as singularity, force, movement, through assemblages or webs of interconnections with all that lives" (Braidotti, 2010, p. 210). Instead of remaining locked in a cultural denial of pain (and general suppression of emotion) what is proposed instead is that we recognise the generative potential of pain, once acknowledged. Braidotti explains 
that this "ethics of transforming negative into positive passions introduces time and motion into the freezing enclosure of seething pain. It is a postsecularist gesture of affirmation of hope, in the sense of creating the conditions for endurance and hence for a sustainable future" (p. 214).

A further shift proposed by Braidotti (2010) is to move away from transactional expectations of mutual reciprocity to a non-demanding generosity and receptivity:

Transformative postsecular ethics takes on the future affirmatively, as the shared collective imagining that goes on becoming, to effect multiple modes of interaction with heterogeneous others. Futurity is made of this. Nonlinear evolution: an ethics that moves away from the paradigm of reciprocity and the logic of recognition and installs a rhizomatic relation of mutual affirmation. (p. 216)

For Braidotti (2009), this "[a]ffirmative ethics puts the motion back into e-motion and the active back into activism, introducing movement, process, becoming" (p. 50), constituting a politics of transformation, through an enduring "shared collective imagining" (p. 56). Our political, ethical and educational response then becomes "multiple micro-political practices of daily activism or interventions in and on the world we inhabit for ourselves and for future generations" (p. 46).

Braidotti's challenge for educationalists is complex. Broadening our ethical spectrum to include relationality with the more-than-human realm inclusive of planetary forces, requires a shift in pedagogical focus away from a predominantly individualistic, secular, cognitive, transactional model, to an affective, applied collective project of affirmative becoming(s). And central to this pedagogy is to foster the affective aliveness, attentiveness and receptivity to the more-than-human world (Abram, 1996, 2010) that is crucial to re-bridging the hardened alienation from nature that has enabled its gratuitous exploitation.

\section{Aotearoa as a bio-region for pedagogies of place and tangata whenuatanga}

The remaining focus of this paper is to bring the previously outlined theorising for pedagogies for sustainabilities into the context of our work as teacher education scholars and educators in Aotearoa, a country with a history of colonisation that has impacted on the ways in which Māori ecological knowledges have been devalued (Penetito, 2009, 2010). Many Māori retain a close sense of relationality with the planet, the Earth Mother Papatūanuku, and the Sky Father, Ranginui considered to be their ancestors, and in each tribal region, strong genealogical connects are felt with local mountains, rivers, and seas, traditional practices of bioregional sustainability evidenced in ongoing advocacy through the Waitangi Tribunal (Waitangi Tribunal, 2011; Williams, 1997).

Iwi and hapu Māori have distinctive, localised relationships with their whenua, maunga, awa, ngāhere and the creatures that inhabit these places and spaces. Penetito (2009) proposes a place-based pedagogy for all students, which is reflective of local Indigeneity. This pedagogical approach is grounded in recognition that "a sense of place is a fundamental human need" (p. 20). It acknowledges that, for Indigenous 
peoples, their sense of relationality with the more-than-human world, their environment and fellow creatures, is one of being 'co-habitors'. A pedagogy embodying Indigenous ways of knowing, being, and doing also involves a proactive "conscious union of mind and spirit" (p. 20).

An important distinction of this pedagogy is that understandings are taught through the local Indigenous culture rather than about it (Kawagley, 2001). Place-based pedagogies offer counter-colonial possibilities, in that they can challenge the "hegemonic process that poses a severe constraint on the Māori capacity to deconstruct and reconstruct a more realistic and optimistic Māori culture" (Penetito, 2009 , p. 22) whilst simultaneously promoting the cultural change required to foster the relationality and affectivity required to address the challenges of sustainabilities.

Tātaiako: Cultural Competencies for Teachers of Māori Learners (Ministry of Education \& New Zealand Teachers Council, 2011) was recently promulgated in an attempt to address the need for teachers in all sectors to have the 'cultural competence' required to meet the expectations of Ka Hikitia (Ministry of Education, 2008). 'Tangata Whenuatanga' is one of the required competencies which involves "affirming Māori learners as Māori; providing contexts for learning where the language, identity and culture of Māori learners and their whānau is affirmed" (p. 4) as well as being "placebased", and requiring "socio-cultural awareness and knowledge" (p. 5). More specific expectations for graduating teachers require that they are able to "explain how knowledge of local context and local iwi and community is important in supporting Māori learners to achieve in and through education" and have "the tools and skills to engage local knowledge and history (or the people who hold that knowledge) to support teaching and learning programmes" (p. 12). And for the registered teacher it is expected that $\mathrm{s} / \mathrm{he}$ "[a]ctively facilitates the participation of whānau and people with the knowledge of local context, tikanga, history, and language to support classroom teaching and learning programmes" and "[c]onsciously uses and actively encourages the use of local Māori contexts (such as whakapapa, environment, tikanga, language, history, place, economy, politics, local icons, geography) to support Māori learners' learning" (p. 12).

For the early childhood sector, the New Zealand early childhood curriculum, Te Whāriki (Ministry of Education, 1996), advocates a pedagogy deeply reflective of te ao Māori alongside Western knowledges, and is intended to benefit all children present. Recent research (Barker, 2010; Duhn, Bachmann, \& Harris, 2010; Ellwood, 2010; Ritchie et al., 2010) has demonstrated a pedagogical focus on 'caring for ourselves, others and the environment', underpinned by kaupapa Māori constructs of manaakitanga (caring, generosity, hospitality) and kaitiakitanga (guardianship). There are some clear links that can be made between the aspirations of Te Wharriki and the notion of 'sustainabilities' being advocated in this paper, which includes consideration of social, economic, relational, cultural, linguistic as well as environmental/ecological sustainabilities.

Social sustainability includes a focus on equity, justice, fairness, and being in community, which is reflected in the Te Whäriki strand of Mana Whenua - Belonging. Economic sustainability highlights aspects such as employment, meaningful contribution, and responsibility in addressing the inequity of poverty, which can all 
be aligned with the Te Whāriki strand, Mana Tangata - Contribution. Relational sustainability includes promoting dispositions of kindness and nonviolence, implementing strategies for promoting peaceful relationships, and emotional and spiritual wellbeing, as well as intra- and inter-personal connectedness, which are central to the Te Whāriki strand, Mana Atua - Wellbeing. Relationality in terms of connectedness with, and responsiveness to, the more-than-human world along with conceptualisations and practices of environmental/ecological sustainability are the concern of the Te Whäriki strand, Exploration - Mana Aotūroa. Cultural and linguistic sustainability are especially pertinent for Māori as their language remains under threat, a concern of Te Whāriki strand, Communication - Mana Reo. Of course, like many other key constructs, these sustainabilities can be seen to interweave across and throughout all the principles, strands and goals of Te Whäriki.

In the following section, several examples from a recent study (Ritchie et al., 2010) will be outlined in order to illustrate some actualities of pedagogical implementation in the service of a commitment to notions of sustainabilities delivered in consideration of ethical relationality grounded in te ao Māori.

\section{Some examples from a recent study}

Our study foregrounded in its title our central ethical focus: Titiro Whakamuri, Hoki Whakamua. We are the future, the present and the past: caring for self, others and the environment in early years' teaching and learning (Ritchie et al., 2010). This ethical positioning drew from both tikanga Māori and Western worldviews, tikanga being literally what is right and correct. Drawing on kaupapa Māori notions of ethical care for ourselves, others and the environment is consistent with Te Whāriki, as are Western understandings of an ethic of care as promoted by Carol Gilligan (1982), Nel Noddings (2005a, 2005b, 2007) and others (Dahlberg \& Moss, 2005; Goldstein, 1998; Martin, 2007; M. Smith, 2001). The study built upon previous research in early childhood education in Aotearoa which had documented ways in which teachers had shifted from 'teaching about' tikanga Māori, to enacting and modelling Māori values such as manaakitanga within everyday routines and pedagogies (Ritchie \& Rau, 2006, 2008). The guiding questions for the project were as follows:

1. What philosophies and policies guide teachers/whannau in their efforts to integrate issues of ecological sustainability into their current practices?

2. How are Māori ecological principles informing and enhancing a kaupapa of ecological sustainability, as articulated by teachers, tamariki and whānau?

3. In what ways do teachers/whannau articulate and/or work with pedagogies that emphasise the interrelationships between an ethic of care for self, others and the environment in local contexts?

4. How do/can centres work with their local community in the process of producing ecologically sustainable practices?

Teachers, children and families from 10 early childhood centres participated in the project, which was conducted during 2008-2009. Our methodology was eclectic utilising narrative (Clandinin \& Huber, 2002; Clandinin et al., 2006; Craig \& Huber, 2007; Hollingsworth \& Dybdahl, 2007; Schulz, Schroeder, \& Brody, 1997); kaupapa 
Māori (Bishop, 2005; L. T. Smith, 1999/2006) and ethnographic modes (Atkinson \& Hammersley, 1998; Eisenhart, 2001; Quantz, 1992; Spindler \& Spindler, 1987). After an initial one-day hui to establish a collective vision regarding ethics and research questions, the four co-directors worked closely with teachers from the centres to gather a wide range of data which included centre documentation such as policies and pedagogical narratives, photographs, video, children's art and stories, and recorded interviews of discussions with and between parents, teachers and codirectors. After the year-long phase of data collection, a second full-day hui took place, again with all the teachers and the project kuia and kaumātua in attendance to share back some of the highlights and learnings from involvement in the project. Powerpoints and audio from this hui contributed another tier of data.

As the project has been reported in detail elsewhere (Barker, 2010; Duhn et al., 2010; Ellwood, 2010; Ritchie et al., 2010) in the space that remains here, I focus on identifying some examples of enactment of ethical relationalities that became evident during the study, demonstrating some of the ways that "teachers and communities are paying attention, in one way or another, to what becoming ethical and responsible means in a world committed to ecological sustainability" (Ritchie et al., 2010, p. 10). For some of the teachers, understanding Māori constructions of genealogical and spiritual interconnectedness (whakapapa and wairua) was a new challenge, whilst for others, particularly those who are Māori, or who had a background within the Enviroschools movement (Enviroschools/Kura Taiao, 2009), these understandings were already embedded in their philosophy:

The research is about Māori ecological principles, how they're informing and enhancing a kaupapa of ecological sustainability [...] the Māori worldview is holistic and cyclic, one in which every person is linked to every living thing and to the atua, which is the Gods. Māori customary concepts are interconnected through our whakapapa, which is your genealogy that links to te taha wairua, which is your spiritual element, and te taha kikokiko, which is your intellect or your body and your whole spirit. (Papamoa Kindergarten)

Teachers sought the support of whānau in uncovering historical knowledges regarding their particular locations:

We thought it's really important to us to share the stories and the legends of our local place [...] It's important to pass on the local legends and knowledge of the land and each place has a significance because of its locality, and it creates an ownership and pride of place for everyone [...] a sense of türangawaewae, a place to belong, within the kindergarten community and not working in isolation but [with] the community. The community has a lot to offer and that's [the] value, being part of it ... This story is about the orca whales who were stranded on [the] beach last year and that was a big thing for our community. (Papamoa Kindergarten)

The teachers were aware of the challenges they faced in recruiting children and families to sustainability notions, in the face of the pervasive consumerist culture 
which many children are exposed to on a daily basis through the bombardment of advertising in media such as television:

There is no question that to live sustainably we have to reduce consumption - how do you do this with kids who are bombarded with messages to consume, who regularly confuse need and want? [...] This is an area that I would really like to continue working at, looking at alternative pleasures, like the joys of receiving and using an item with a history attached to it; giving home-made presents (Collectively Kids)

An interesting feature at a number of the centres, particularly as the children's enthusiasm for gardening resulted in surpluses of garden produce, was the establishment of some form of reciprocal sharing of abundant or excess fruit or vegetables grown in homes or at the centre. This also extended to a flow of re-using clothing, toys and books. This was a tangible, practical enactment of manaakitanga, of "an endless cycle of reciprocity" (Waitangi Tribunal, 2004, p. 4). One example of this was the 'OOOOBY' (Out of our own back yards, 2011) bowl at Raglan Childcare and Education Centre:

I noticed an ad in the Waiheke local newspaper about a new initiative on the island to bring together people interested in growing and eating out of our own back yards (OOOBY Store). We have been harvesting tomatoes and cape gooseberries from our own garden here at Raglan Childcare. I introduced an OOOBY bowl to see if parents wanted to join in and contribute from home. Over the next month we received some yummy fruit and vegetables. A memorable-sized watermelon from E's family was shared [...]. An enormous marrow was carved into a whale. The OOOBY bowl has sparked off different activities like juicing and experimenting with taste and colour. Making our own tomato sandwiches at kai time, cooking and eating sweetcorn. Tasting and identifying new things like pepino from Merryn's garden. (Raglan Childcare and Education Centre)

Raglan Childcare and Education Centre staff, families and children also gathered a container-load of books, clothes and toys to send to Kenya, timed to arrive when a Kenyan early childhood teacher who had visited their centre was returning home so that she could distribute these in her village. Meanwhile, the teaching team at Richard Hudson Kindergarten set up a 'free shelf', which expanded to include clothes, toys, books, plants, cuttings and so on, and at Bellmont Kindergarten Te Kupenga, a 'community basket' was initiated by a parent:

A parent said, "Can we hang up a basket and if we've got any extra produce at home I'll bring it and put it in there?" Because they grow their own stuff and so people bring things and put them in the community basket and there's a bag and packets and people come and help themselves. And at the end of the citrus season we just said to people, "Anyone got lots of citrus at their place that's just lying around wasting?" and one little girl's grandparents brought in bags 
and bags of oranges, lemons, mandarins, whatever and we just shared it with all the whannau [...] because some of the families here really struggle. We're in an interesting mix of families and [...] part of our philosophy is just sharing kai, growing kai for us all to enjoy. (Bellmont Kindergarten Te Kupenga)

These few examples from the many that were illuminated during the project, demonstrate an ethics of collectivity, rather than individualism, informed by kaupapa Māori values such as manaakitanga, and by local Māori histories related to those particular places and respectful of 'co-habitants' such as visiting orca. They demonstrate transformations at the community level that transcend consumerist edicts to buy, sell, or profit, instead recognising that there are ways to support the wellbeing of others which are not necessarily transactional or reciprocal, but ultimately reflect an ethic of care, generating a different way of being, one that is inherently aware of our interconnectedness as planetary citizens.

\section{Conclusion}

\section{The importance of ongoing enactment}

The examples provided above might provide a small glimpse of potentialities for pedagogies that are infused with an everyday ethicality of relationality which reflects concern for the more-than-human world, and brings local Indigenous understandings to the fore. The situation of our planet's and our fellow co-habitants' wellbeing is the major ethical crisis of our age. It is imperative that we mobilise ourselves beyond pain and denial and into action on as many fronts as possible, and as soon as possible.

Climate change isn't simply a problem of politics or economics, it's a problem of ethics. Choices we are making today are going to determine the world that we leave our children and grandchildren and there is still time to make the right choices. (Mann, 2011)

As UNESCO has recognised, the positioning of educators holds enormous transformational potential, a potential that can be directed in service of the wellbeing of our planet. It is important that this education provision be informed by relevant research.

\section{Glossary}

$\begin{array}{ll}\text { Atua } & \text { gods } \\ \text { Awa } & \text { river(s) } \\ \text { Hapu } & \text { sub-tribe } \\ \text { Hui } & \text { meeting, gathering } \\ \text { Iwi } & \text { tribe } \\ \text { Kai } & \text { food } \\ \text { Kaitiakitanga } & \text { guardianship } \\ \text { Kaumātua } & \text { elder } \\ \text { Kaupapa } & \text { philosophy } \\ \text { Kuia } & \text { female elder }\end{array}$




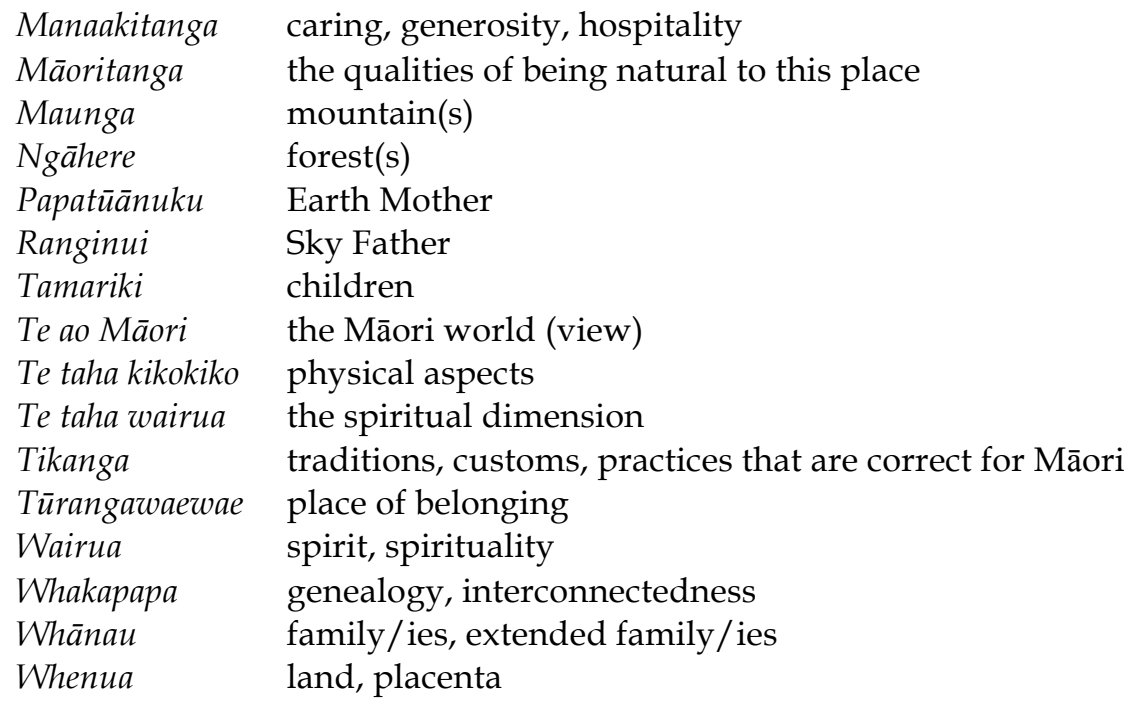

\section{Acknowledgements}

The project received ethical approval from the Unitec Research Ethics Committee. For further details regarding the methodology, and detailed reporting of data please see the final report, available at http://www.tlri.org.nz/sites/default/files/ projects/9260-finalreport.pdf. Centres and individual names are used with permission. I want to especially acknowledge the collegiality, support and hard work of the other co-directors of our project: Janita Craw, Iris Duhn and Cheryl Rau and of the educator co-researchers, as well as the Teaching and Learning Research Initiative for our funding.

\section{Correspondence}

Jenny Ritchie, Associate Professor, Early Childhood Teacher Education, Te Whare Wānanga o Wairaka - Unitec Institute of Technology, Auckland, New Zealand. Email: jritchie@unitec.ac.nz

\section{References}

Abram, D. (1996). The spell of the sensuous. Perception and language in a more-thanhuman world. New York, NY: Vintage Books.

Abram, D. (2010). Becoming animal. An earthly cosmology. New York, NY: Vintage.

Atkinson, P., \& Hammersley, M. (1998). Ethnographic research and participant observation. In N. K. Denzin \& Y. S. Lincoln (Eds.), Strategies of qualitative inquiry (pp. 110-136). Thousand Oaks, CA: Sage.

Barker, G. (2010). Building sustainable communities. 'Manaaki whenua. Manaaki tangata. Haera whakamua'. Early Education, 47, 15-18.

Bishop, R. (2005). Freeing ourselves from neocolonial domination in research: A kaupapa Māori approach to creating knowledge. In N. K. Denzin \& Y. S. 
Lincoln (Eds.), The Sage handbook of qualitative research (3rd ed., pp. 109-164). Thousand Oaks, CA: Sage.

Braidotti, R. (2006). Posthuman, all too human: Towards a new process ontology. Theory, Culture \& Society, 23(7-8), 197-208.

Braidotti, R. (2007). Feminist epistemology after postmodernism: Critiquing science, technology and globalisation. Interdisciplinary Science Reviews, 32(1), 65-73.

Braidotti, R. (2009). On putting the active back into activism. New Formations, 68, 4257. doi:10.3898/newf.3868.3803.2009

Braidotti, R. (2010). The politics of 'life itself' and new ways of dying. In D. Coole \& S. Frost (Eds.), New materialisms. Ontology, agency, and politics (pp. 201-218). Durham \& London, UK: Duke University Press.

Clandinin, D. J., \& Huber, J. (2002). Narrative Enquiry: Toward understanding life's artistry. Curriculum Inquiry, 32(2), 161-169.

Clandinin, D. J., Huber, J., Huber, M., Murphy, M. S., Orr, A. M., Pearce, M., \& Steeves, P. (2006). Composing diverse identities. Narrative inquiries into the interwoven lives of children and teachers. London, UK \& New York, NY: Routledge.

Coole, D., \& Frost, S. (2010). Introducing the new materialisms. In D. Coole \& S. Frost (Eds.), New materialisms. Ontology, agency, and politics (pp. 1-43). Durham \& London, UK: Duke University Press.

Craig, C. J., \& Huber, J. (2007). Relational reverberations. Shaping and reshaping narrative inquiries in the midst of storied lives and contexts. In D. J. Clandinin (Ed.), Handbook of narrative inquiry. Mapping a methodology (pp. 251-279). Thousand Oaks, CA: Sage.

Curry, P. (2011). Ecological ethics. An introduction. Cambridge, UK: Polity Press.

Dahlberg, G., \& Moss, P. (2005). Ethics and politics in early childhood education. London, UK: Routledge.

Davidson, K. M. (2011). Reporting systems for sustainability: What are they measuring? Social Indicators Research, 100(2), 351-365.

Deleuze, G., \& Guattari, F. (2004a). Anti-oedipus. capitalism and schizophrenia (R. Hurley, M. Seem, \& H. R. Lane, Trans.). London, UK \& New York, NY: Continuum.

Deleuze, G., \& Guattari, F. (2004b). A thousand plateaus. Capitalism and schizophrenia (B. Massumi, Trans.). London, UK \& New York, NY: Continuum.

Duhn, I., Bachmann, M., \& Harris, K. (2010). Becoming ecologically sustainable in early childhood education. Early Childhood Folio, 14(1), 2-7.

Eisenhart, M. (2001). Educational ethnography past, present, and future: Ideas to think with. Educational Researcher, 30(8), 16-27. 
Ellwood, A. (2010). Caring for Papatuanuku. Yesterday, today and tomorrow. Early Education, 47(Autumn/Winter), 19-22.

Enviroschools/Kura Taiao. (2009). Tā tātou kaupapa. About Enviroschools. Retrieved from http:/ / www.enviroschools.org.nz/about-enviroschools

Gilligan, C. (1982). In a different voice: Psychological theory and women's development. Cambridge, MA: Harvard University Press.

Goldstein, L. (1998). More than gentle smiles and warm hugs: Applying the ethic of care to early childhood education. Journal of Research in Childhood Education, 12(2), 244-262.

Hansen, J. (2009). Storms of my grandchildren. The truth about the coming climate catastrophe and our last chance to save humanity. London, UK: Bloomsbury.

Haraway, D. J. (1997). Modest_Witness@Second_Millennium.FemaleMan@_Meets _OncoMouse ${ }^{\mathrm{TM}}$. Feminism and technoscience. New York, NY: Routledge.

Haraway, D. J. (2000). How like a leaf. An interview with Thyrza Nichols Goodeve. New York, NY: Routledge.

Haraway, D. J. (2008). When species meet. Minneapolis, MN: University of Minnesota Press.

Hollingsworth, S., \& Dybdahl, M. (2007). The critical role of conversation in narrative inquiry. In D. J. Clandinin (Ed.), Handbook of narrative inquiry. Mapping a methodology (pp. 146-176). Thousand Oaks, CA: Sage.

Kawagley, A. O. (2001). Spirit, knowledge, and vision from our first nations' sages. Canadian Journal of Native Education, 25(2), 199-206.

Kolbert, E. (2009, June 29). The catastrophist. The New Yorker, 39-45.

Magdoff, F., \& Foster, J. B. (2011). What every environmentalist needs to know about capitalism. A citizen's guide to capitalism and the environment. New York, NY: Monthly Review Press.

Mann, M. (2011). A look into our climate: Past to present to future. Retrieved from http:/ / www.youtube.com/watch?v=ElI-XVGHCHs.

Marsden, M. (2003). The woven universe. Selected writings of Rev. Māori Marsden. T. A. C. Royal (Ed.). Wellington, NZ: The Estate of Māori Marsden.

Martin, P. (2007). Caring for the environment: Challenges from notions of caring. Australian Journal of Environmental Education, 23, 57-64.

Ministry of Education. (1996). Te Whāriki. He whāriki mātauranga mō ngā mokopuna o Aotearoa: Early childhood curriculum. Wellington, NZ: Learning Media. Retrieved from http://www.educate.ece.govt.nz/ /media/Educate/Files/ Reference\%20Downloads/whariki.pdf

Ministry of Education. (2008). Ka Hikitia. Managing for Success. Māori Education Strategy 2008-2012. Wellington, NZ: Ministry of Education. 
Ministry of Education, \& New Zealand Teachers Council. (2011). Tātaiako: Cultural competencies for teachers of Mäori learners. Wellington, NZ: Authors. Retrieved from http://www.akoaotearoa.ac.nz/mi/download/ng/file/group-199/aliterature-review-of-kaupapa-maori-and-maori-education-pedagogy.pdf

Noddings, N. (2005a). Global citizenship: Promises and problems. In N. Noddings (Ed.), Educating citizens for global awareness (pp. 1-21). New York, NY: Teachers College Press.

Noddings, N. (2005b). Place-based education to preserve the Earth and its people. In N. Noddings (Ed.), Educating citizens for global awareness (pp. 57-68). New York, NY: Teachers College Press.

Noddings, N. (2007). Philosophy of education (2nd ed.). Boulder, CO: Westview Press.

Out of our own back yards. (2011). Out of our own back yards. Retrieved from http://www.ooooby.org/

Penetito, W. (2009). Place-based education: Catering for curriculum, culture and community. New Zealand Annual Review of Education, 18, 2008, 5-29.

Penetito, W. (2010). What's Māori about Māori education? Wellington, NZ: Victoria University Press.

Plumwood, V. (1999). Ecological ethics from rights to recognition. In N. Low (Ed.), Global Ethics and Environment (pp. 188-212). New York, NY: Routledge.

Plumwood, V. (2002). Environmental culture. The ecological crisis of reason. London, UK \& New York, NY: Routledge.

Plumwood, V. (2006). The concept of a cultural landscape. Nature, culture and agency in the land. Ethics and the Environment, 11(2), 115-150.

Quantz, R. A. (1992). On critical ethnography (with some postmodern considerations). In M. D. LeCompte, W. L. Millroy, \& J. Preissle (Eds.), The handbook of qualitative research in education (pp. 447-501). San Diego, CA: Academic Press.

Riley-Taylor, E. (2003). Relational knowing: An ecological perspective on curriculum. Journal of Curriculum Theorizing, 79(3), 39-50.

Ritchie, J., Duhn, I., Rau, C., \& Craw, J. (2010). Titiro Whakamuri, Hoki Whakamua. We are the future, the present and the past: caring for self, others and the environment in early years' teaching and learning. Final Report for the Teaching and Learning Research Initiative. Wellington, NZ: Teaching and Learning Research Initiative/New Zealand Centre for Educational Research. Retrieved from http:/ / www.tlri.org.nz/sites/default/files/projects/9260-finalreport.pdf

Ritchie, J., \& Rau, C. (2006). Whakawhanaungatanga. Partnerships in bicultural development in early childhood education. Final Report to the Teaching \& Learning Research Initiative Project. Wellington, NZ: Teaching Learning Research Institute/New Zealand Centre for Educational Research. Retrieved from: http://www.tlri.org.nz/pdfs/9207_finalreport.pdf 
Ritchie, J., \& Rau, C. (2008). Te Puawaitanga - partnerships with tamariki and whannau in bicultural early childhood care and education. Final Report to the Teaching Learning Research Initiative. Wellington, NZ: Teaching Learning Research Institute/New Zealand Centre for Educational Research. Retrieved from http:// www.tlri.org.nz/pdfs/9238_finalreport.pdf

Rose, N. (2001). The politics of life itself. Theory, Culture E Society, 18(1), 1-30.

Scatamburlo-D'Annibale, V., \& McLaren, P. (2009). The reign of capital. A pedagogy and praxis of class struggle. In M. Apple, W. Au, \& L. A. Gandin (Eds.), The Routledge international handbook of critical education (pp. 96-109). New York, NY: Routledge.

Schulz, R., Schroeder, D., \& Brody, C. M. (1997). Collaborative narrative inquiry: fidelity and the ethics of caring in teacher research. Qualitative Studies in Education, 10(4), 473-485.

Smith, L. T. (1999/2006). Decolonizing methodologies. Research and indigenous peoples. London, UK and Dunedin, NZ: Zed Books Ltd and University of Otago Press.

Smith, M. (2001). An ethics of place. Radical ecology, postmodernity, and social theory. Albany, NY: State University of New York Press.

Spindler, G., \& Spindler, L. (1987). Teaching and learning how to do the ethnography of education. In G. Spindler \& L. Spindler (Eds.), Interpretive ethnography of education at home and abroad (pp. 17-33). Hillsdale, NJ: Lawrence Erlbaum.

Tuck, E. (2010). Breaking up with Deleuze: Desire and valuing the irreconcilable. International Journal of Qualitative Studies in Education, 23(5), 635-650.

UNESCO. (2005). Guidelines and Recommendations for Reorienting Teacher Education to Address Sustainability. Education for Sustainable Development in Action Technical Paper $N^{\circ} 2$ - 2005. UNESCO Education Sector, Division for the Promotion of Quality Education, Paris, France: Author.

UNESCO. (2010). UNESCO Chair on Reorienting Teacher Education to Address Sustainability: International Network. Toronto, Canada: Author. Retrieved from http://www.unesco.org/en/esd/networks/teacher-education/

Waitangi Tribunal. (2004). Report on the Crown's foreshore and seabed policy. Wai 1071. Wellington, NZ: Legislation Direct. Retrieved from http://www.waitangitribunal.govt.nz/reports/viewchapter.asp?reportID=838C5579-36C3-4CE2A444-E6CFB1D4FA01\&chapter=3.

Waitangi Tribunal. (2011). Ko Aotearoa tenei. A report into claims concerning New Zealand law and policy affecting Māori culture and identity. Te taumata tuatahi. Wai 262. Wellington, NZ: Waitangi Tribunal.

Williams, D. (1997). Traditional kaitiakitanga rights and responsibilities. In Mātauranga Māori and taonga. The nature and extent of Treaty rights held by iwi and hapu in indigenous flora and fauna cultural heritage objects and traditional knowledge (pp. 97-147). Wellington, NZ: Waitangi Tribunal. Retrieved from 
http://www.waitangi-tribunal.govt.nz/inquiries/genericinquiries2/

florafauna/mtaurangamoriandtaonga.asp

\section{Biographical notes}

Jenny Ritchie's teaching, research, and writing has focused on supporting early childhood educators and teacher educators to enhance their praxis in terms of cultural, environmental and social justice issues. She has recently led three consecutive, two-year studies funded by the New Zealand Teaching and Learning Research Initiative.

Manuscript received: January 2, 2012

Manuscript revised: January 10, 2013

Accepted: February 23, 2013 